\title{
A Review on COVID-19: Origin, Spread, Symptoms, Treatment, and Prevention
}

\author{
Angham G. Hadi ${ }^{1(\mathbb{D})}$, Mohammed Kadhom ${ }^{2(\mathbb{C})}$, Nany Hairunisa ${ }^{3(\mathbb{D})}$, Emad Yousif ${ }^{4, *(\mathbb{D})}$, Salam A. \\ Mohammed 5 (iD \\ Department of Chemistry, College of Science, University of Babylon, Babylon, Iraq \\ Department of Environment, College of Energy and Environmental Sciences, Alkarkh University of Science, Baghdad, \\ Iraq \\ Department of Occupational Medicine, Faculty of Medicine, Trisakti University. Jakarta, Indonesia \\ 4 Department of Chemistry, College of Science, Al-Nahrain University, Baghdad, Iraq \\ 5 Department of Chemical and Petrochemical Engineering, College of Engineering and Architecture, University of Nizwa, \\ Oman \\ * Correspondence: emad_yousif@hotmail.com;
}

Scopus Author ID 26533612800

Received: 4.05.2020; Revised: 1.06.2020; Accepted: 3.06.2020; Published: 7.06.2020

\begin{abstract}
A novel type of coronavirus, identified as 2019-nCoV or COVID-19, appeared in Wuhan, China, in late 2019 and continued to spread in 2020. On January $24^{\text {th }}, 2020$, about 830 cases were reported in nine countries, namely: China, Japan, Singapore, Thailand, South Korea, Nepal, Vietnam, the United States, and Taiwan. Also, about 26 confirmed deaths have been recorded, especially for patients with serious underlying diseases. On March $11^{\text {th }}$, 2020, the World Health Organization (WHO) declared COVID-19 as a global pandemic. Until June $3^{\text {rd }}$, 2020, this outbreak virus caused over $6,500,000$ detected infection cases in 210 countries and territories and around 383,000 confirmed death cases. Although information about the appearance of the virus, i.e., its origin and capacity to spread among people, is still unclear, there are growing numbers of cases that are occurring from the communication of infected people with uninfected ones. 2019-nCoV is the third coronavirus which was detected in humans in the past two decades, after SARS-CoV and Middle Eastern Respiratory Coronavirus (MERS-CoV) that appeared in 2002 and 2012, respectively. In this review, we summarized the up-to-date information regarding COVID-19's origin, ways of spread, patients' symptoms, treatment, and prevention.
\end{abstract}

Keywords: COVID-19; cough; SARS-CoV; RNA; 2019-nCoV; coronavirus

(C) 2020 by the authors. This article is an open-access article distributed under the terms and conditions of the Creative Commons Attribution (CC BY) license (https://creativecommons.org/licenses/by/4.0/).

\section{Introduction}

Coronavirus (CoV) belongs to the family of single-stranded RNA viruses, that relates to the order of Nidoviral. This order contains, in general, the families of Coronaviridae, Roniviridae, and Arteriviridae. The Coronaviridae family can be divided into Coronavirinae and Torovirinae; however, it can also be divided into alpha, beta, gamma, and delta [1-6]. The viral RNA genome length could extend from 26 to $32 \mathrm{kPa}$ and insulated from diverse kinds of animals, such as cats, birds, camels, dogs, bats, mice, and livestock [7-10]. The proliferation and spread of CoVs put the human in serious nursing conditions. The first detection of the MERS-CoV virus was in Saudi Arabia in 2012, where about 2,494 cases were registered, among them 858 cases of death. In 2002, a subspecies of beta volatile organic compound quickly spread to Guangdong, China, where the epidemic left 8,000 people hurt and 774 dead in 37 countries [11-18]. The pandemic in 2020 was introduced as pneumonia of unknown 
causes in China. Laboratory investigations and a series of reports have recognized the attacker as a different strain of coronaviruses [19-25]. At first, the virus was classified as 2019-nCoV; also, it was classified as SARS-CoV-2, according to the International Classification of Viruses (ICV) [26-30]. The nowadays most famous name of this new virus is COVID-19, which was stated by the World Health Organization published on February 11th, 2020.

\section{Origin and spread}

In December 2019, in Wuhan, adults went to local hospitals with the severe respiratory syndrome for an unknown reason. The control system (developed after SARS disease spreading) and patients' respiratory samples were sent to reference laboratories to discover the cause. On December $31^{\text {st }}, 2019$, China informed the WHO about the outbreak, and on January $1^{\text {st }}, 2020$, Huanan seafood shops were closed. On January 7 th, the virus was recognized as a coronavirus that has about $95 \%$ symmetry with coronary bat virus and about $70 \%$ similarity to SARSCoV. Samples that were taken from the Huanan seafood market's objects and animals were also positive, indicating that this virus is generated from seafood [31-38]. Next, the case numbers started to increase steadily, suggesting that person-to-person transmission occurred because some of these cases have not present in the animal market [39-46]. On January $11^{\text {th }}$, the first fatality case was reported due to Chinese heavy transportation through the Chinese New Year, which fueled the pandemic. The population of Wuhan is around 11 million, where they were put into custody with entry and exit restrictions. Soon, this virus spread to other cities in Hubei province. On January $23^{\text {rd }}$, other cases appeared (very quickly) in Japan, South Korea, and Thailand besides China. [47-53].

The infection continued with a sharp increase; modeling reports have resulted in a multiple pandemic time of $1.8 \mathrm{~d}$ [53-59]. On February $12^{\text {th }}$, the definition of confirmed cases, including patients with negative/suspended molecular tests, was changed by China. Thereby, the medical, radiological, besides epidemiological COVID-19 profiles were updated and lead to a rise in cases by about 15,000 in one day. On March 3rd, 2020, around 96000 cases around the world (80,000 in China) were confirmed, located in 87 countries and 1 international transportation facility (696 in the Diamond cruise ship). The number of new cases has dramatically increased in new countries, such as Iran, South Korea, and Italy, while it started to decrease in China simultaneously. Today, COVID-19 cases in China has the lowest growth rate comparing with other high cases countries, and the outbreak seems to be almost in control.

\section{Symptoms}

Almost similar to its predecessor, SARS, the symptoms of COVID-19 make infected people feel with symptoms like the flu ones. Though symptoms appeared on infected people could differ from a person to another; this virus is affecting different people in different ways. Most of the infected people could experience mild to moderate symptoms. The symptoms are "commonly" fever $\left(>38{ }^{\circ} \mathrm{C}\right)$, fatigue, and dry cough [60-65]. Some people may experience aches and pains, nasal congestion, cold, sore throat, dyspnea, and diarrhea. Recently, the center of disease control (CDC) has added symptoms that may be felt by infected people, namely, chills, muscle aches, trembling, headaches, and loss of smell and taste. It may take an average of 5-6 days for the infected person to show symptoms, but in some cases, it could take up to 14 days [66-72]. 


\section{Treatment}

First of all, isolation must be applied in order to prevent transmission of infection to new contacts. Mild illnesses should be treated at home while maintaining the ill person's body hydrated, controlling fever and cough, consuming nutrition, and using antibiotics regularly. It was suggested by China Oseltamivir Guidelines to avoid antivirals in short-term treatment; also, corticosteroids could be used in acute respiratory distress syndrome (ARDS) COVID-19 [73-75]. The WHO has published a detailed guide for critical care management, which could be updated according to new findings [18-25]. There is no fully approved therapy for COVID19 yet, although researches are still ongoing. Antiviral drugs, for example, ribavirin and lopinavir/ritonavir, were found beneficial based on the experience from SARS and MERS. Before recommending these drugs, we need more evidence. Further medicines are suggested for pro treatments, such as chloroquine, arbidol, intravenous immunoglobulin, plasma, and interferon [2, 55-58], in addition to using traditional Chinese herbs [76-77].

Grein et al. conducted a study of using remdesivir on 53 patients who received at least one dose of the medication. Basically, 30 patients, $57 \%$ of the total number, needed mechanical ventilation, and 4 patients (8\%) have treated with extracorporeal membrane oxygenation. The follow-up period was 18 days, where 36 patients (68\%) experienced an increase in oxygen support, including 17 among 30 patients (57\%) who received extubated mechanical ventilation. It was reported that 25 patients (47\%) have successfully recovered, and seven patients (13\%), unfortunately, died. Death cases were 18\% (6 out of 34) among patients who received invasive ventilation and 5\% (1 of 19) among those who did not obtain invasive ventilation [78].

In a study by Shen et al. [79] about administrating blood plasma therapy obtained from COVID-19 patients who had recovered, 5 patients received mechanics ventilation. After treated with plasma transfusion, body temperature became normal in 3 days for 4 out of the 5 patients, sequential organ failure assessment (SOFA) scores decreased, and $\mathrm{P}_{\mathrm{AO} 2} /$ FIO increased in 12 days (range: 172-276 before and 284-366 after). Viral load also decreased and became negative within 12 days after the transfusion. From this achievement of their clinical findings, it can be concluded that the administration of plasma is quite effective, but because the sample is limited, further clinical trials are needed with a larger sample size [79].

\section{Prevention}

It is important to prevent this disease because there is no reliable treatment since the disease is not fully identified. Reports started to show up claiming that a vaccine and/or medication were found, but it could take up to a year to be used since it takes several stages to be approved finally. However, this made prevention difficult due to the possible chance of infection even before symptoms onset. Therefore, approved or expected cases should be isolated at home, where ventilation and sunlight should be allowed. A mask is required to be worn for the patients and care providers while they are in contact or in the same room with patients, and must wash their hands frequently with soap and water or use hand sanitizer each 15-20 min.

Regarding the community level, people are required to keep social and physical distancing, avoid swarming places, and delay or cancel the unnecessary trips. They must also practice cough hygiene via coughing in sleeves/ tissues instead of hands, in addition to practicing hand cleaning every 15-20 min. Furthermore, surgical masks should be used for patients with respiratory symptoms. The WHO banned the public use of respirator masks and 
restricted their use for health workers. While healthy people are recommended to wear cloth masks when they show up outside or in public areas. Recently, China has enacted legislation prohibiting the sale and trade of wild animals [80-91]. Also, some countries have conducted lockdowns and multiple social restrictions to break the chain of COVID-19 transmission [92101].

\section{Conclusions}

The outbreak of this new virus has affected public, economic, and medical health infrastructure in almost all countries worldwide. Only time will reveal the impact of this virus's on our existence here in Iraq, Indonesia, and the other countries. Therefore, future outbreaks of viruses and pathogens from animal origin can continue. Hence, regardless of the way of curbing the outbreak of this disease, additional efforts are needed to develop thorough actions and avoid outbreaks of zoonotic and non-zoonotic diseases in the future. Ultimately, it is required for people to adhere to general cleaning teachings, the etiquette of hygiene, and avoid eating raw foods and forbidden meat.

\section{Funding}

The authors declare that they didn't receive any type of fund.

\section{Acknowledgments}

The authors like to thank their affiliation universities for partially supporting this work, namely: the University of Babylon, Alkarkh University of Science, Trisakti University, Al-Nahrain University, and the University of Nizwa.

\section{Conflicts of Interest}

The authors declare no conflict of interest.

\section{References}

1. Monajjemi, M.; Shahriari, S.; Mollaamin, F. Evaluation of Coronavirus Families \& Covid-19 Proteins: Molecular Modeling Study. Biointerface Res. Appl. Chem. 2020, 10, 6039-6057, https://doi.org/10.33263/BRIAC105.60396057.

2. Roy, A.; Kucukural, A.; Zhang, Y. I-TASSER: a unified platform for automated protein structure and function prediction. Nature Protocols 2010, 5, 725-738, https://doi.org/10.1038/nprot.2010.5.

3. Molecular Operating Environment (MOE), 2019.01; Chemical Computing Group ULC, 1010 Sherbrooke St. West, Suite \#910, Montreal, QC, Canada, H3A 2R7, 2019.

4. Báez-Santos, Y.M.; Barraza, S.J.; Wilson, M.W.; Agius, M.P.; Mielech, A.M.; Davis, N.M.; Baker, S.C.; Larsen, S.D.; Mesecar, A.D. X-ray Structural and Biological Evaluation of a Series of Potent and Highly Selective Inhibitors of Human Coronavirus Papain-like Proteases. Journal of Medicinal Chemistry 2014, 57, 2393-2412 https://doi.org/10.1021/jm401712t.

5. Hilgenfeld, R. From SARS to MERS: crystallographic studies on coronaviral proteases enable antiviral drug design. The FEBS Journal 2014, 281, 4085-4096, https://doi.org/10.1111/febs.12936.

6. Peersen, O.B. Picornaviral polymerase structure, function, and fidelity modulation. Virus Res. 2017, 234, 420, https://doi.org/10.1016/j.virusres.2017.01.026.

7. Báez-Santos, Y.M.; Barraza, S.J.; Wilson, M.W.; Agius, M.P.; Mielech, A.M.; Davis, N.M.; Baker, S.C.; Larsen, S.D.; Mesecar, A.D. X-ray Structural and Biological Evaluation of a Series of Potent and Highly Selective Inhibitors of Human Coronavirus Papain-like Proteases. Journal of Medicinal Chemistry 2014, 57, 2393-2412, http://dx.doi.org/10.1021/jm401712t.

8. Woo, P.C.Y.; Lau, S.K.P.; Lam, C.S.F.; Lau, C.C.Y.; Tsang, A.K.L.; Lau, J.H.N.; Bai, R.; Teng, J.L.L.; Tsang, C.C.C.; Wang, M.; Zheng, B.J.; Chan, K.H.; Yuen, K.Y. Discovery of seven novel Mammalian and avian coronaviruses in the genus deltacoronavirus supports bat coronaviruses as the gene source of 
alphacoronavirus and betacoronavirus and avian coronaviruses as the gene source of gammacoronavirus and deltacoronavirus. J Virol 2012, 86, 3995-4008, https://doi.org/10.1128/JVI.06540-11.

9. Morfopoulou, S.; Brown, J.; Davies, E.; Anderson, G.; Virasami, A.; Qasim, W.; Chong, W.; Hubank, M.; Plagnol, V.; Desforges, M.; Jacques, T.; Talbot, P.; Breuer, J. Human Coronavirus OC43 Associated with Fatal Encephalitis. New England Journal of Medicine 2016, 375, 497-498, https://doi.org/10.1056/NEJMc1509458.

10. Mayer, K.; Nellessen, C.; Hahn-Ast, C.; Schumacher, M.; Pietzonka, S.; Eis-Hubinger, A.M.; Drosten, C.; Brossart, P.; Wolf, D. Fatal outcome of human coronavirus NL63 infection despite successful viral elimination by IFN-alpha in a patient with newly diagnosed ALL. Eur J Haematol 2016, 97, 208-210, https://doi.org/10.1111/ejh.12744.

11. Al-Khannaq, M.N.; Ng, K.T.; Oong, X.Y.; Pang, Y.K.; Takebe, Y.; Chook, J.B.; Hanafi, N.S.; Kamarulzaman, A.; Tee, K.K. Molecular epidemiology and evolutionary histories of human coronavirus OC43 and HKU1 among patients with upper respiratory tract infections in Kuala Lumpur, Malaysia. Virol J 2016, 13, https://doi.org/10.1186/s12985-016-0488-4.

12. Cui, J.; Li, F.; Shi, Z.L. Origin and evolution of pathogenic coronaviruses. Nat. Rev. Microbiol. 2019, 17 , 181-192, https://doi.org/10.1038/s41579-018-0118-9.

13. Oong, X.Y.; Ng, K.T.; Takebe, Y.; Ng, L.J.; Chan, K.G.; Chook, J.B.; Kamarulzaman, A.; Tee, K.K. Identification and evolutionary dynamics of two novel human coronavirus OC43 genotypes associated with acute respiratory infections: Phylogenetic, spatiotemporal and transmission network analyses. Emerg. Microbes Infect. 2017, 6, https://doi.org/10.1038/emi.2016.132.

14. Lau, S.K.; Lee, P.; Tsang, A.K.; Yip, C.C.; Tse, H.; Lee, R.A.; So, L.Y.; Lau, Y.L.; Chan, K.H.; Woo, P.C.; Yuen, K.Y. Molecular epidemiology of human coronavirus OC43 reveals evolution of different genotypes over time and recent emergence of a novel genotype due to natural recombination. J Virol 2011, 85, 1132511337, https://doi.org/10.1128/jvi.05512-11.

15. Menachery, V.D.; Yount, B.L., Jr.; Sims, A.C.; Debbink, K.; Agnihothram, S.S.; Gralinski, L.E.; Graham, R.L.; Scobey, T.; Plante, J.A.; Royal, S.R.; Swanstrom, J.; Sheahan, T.P.; Pickles, R.J.; Corti, D.; Randell, S.H.; Lanzavecchia, A.; Marasco, W.A.; Baric, R.S. SARS-like WIV1-CoV poised for human emergence. Proc Natl Acad Sci U S A 2016, 113, 3048-3053, https://doi.org/10.1073/pnas.1517719113.

16. Liu, X.; Zhang, B.; Jin, Z.; Yang, H.; Rao, Z. The crystal structure of 2019-nCoV main protease in complex with an inhibitor N3. To be published. PDB code 6LU7 2019, http://dx.doi.org/10.1038/s41586-020-2223$\mathrm{y}$.

17. Yang, Y.; Liu, C.; Du, L. Y.; Jiang, S.; Shi, Z.; Baric, R.S.; Li, F. Two mutations were critical for bat-tohuman transmission of Middle East Respiratory Syndrome coronavirus. J. Virol. 2015, 89, 9119-9123, https://doi.org/10.1128/JVI.01279-15.

18. De Haan, C.A.; Rottier, P.J. Molecular interactions in the assembly of coronaviruses. Adv Virus Res. 2005, 64, 165-230, https://doi.org/10.1016/S0065-3527(05)64006-7.

19. Masters, P.S. The molecular biology of coronaviruses. Adv Virus Res. 2006, 66, 193-292, https://doi.org/10.1016/S0065-3527(06)66005-3.

20. Raamsman, M.; Locker, J.; Hooge, A.; De Vries, A.; Griffiths, G.; Vennema, H.; Rottier, P. Characterization of the Coronavirus Mouse Hepatitis Virus Strain A59 Small Membrane Protein E. J Virol 2000, 74, 23332342, https://doi.org/10.1128/JVI.74.5.2333-2342.2000.

21. Blau, D.M.; Holmes, K.V. Human coronavirus HCoV-229E enters susceptible cells via the endocytic pathway. Adv Exp Med Biol. 2001, 494, 193-8, https://doi.org/10.1007/978-1-4615-1325-4_31.

22. Chu, V.C.; McElroy, L.J.; Ferguson, A.D.; Bauman, B.E.; Whittaker, G.R. Avian infectious bronchitis virus enters cells via the endocytic pathway. Adv Exp Med Biol. 2006, 581, 309-312, https://doi.org/10.1007/9780-387-33012-9_54.

23. Eifart, P.; Ludwig, K.; Bottcher, C.; de Haan, C.A.; Rottier, P.J.; Korte, T.; Herrmann, A. Role of endocytosis and low $\mathrm{pH}$ in murine hepatitis virus strain A59 cell entry. J Virol 2007, 81, 10758-10768, https://doi.org/10.1128/jvi.00725-07.

24. Graham, R.L.; Baric, R.S. Recombination, reservoirs, and the modular spike: mechanisms of coronavirus cross-species transmission. J Virol. 2010, 84, 3134-3146, https://doi.org/10.1128/JVI.01394-09.

25. Bárcena, M.; Oostergetel, G.T.; Bartelink, W.; Faas, F.G.A.; Verkleij, A.; Rottier, P.J.M.; Koster, A.J.; Bosch, B.J. Cryo-electron tomography of mouse hepatitis virus: Insights into the structure of the coronavirion. Proceedings of the National Academy of Sciences 2009, 106, https://doi.org/10.1073/pnas.0805270106.

26. Lewicki, D.N.; Gallagher, T.M. Quaternary structure of coronavirus spikes in complex with carcinoembryonic antigen- related cell adhesion molecule cellular receptors. J Biol Chem. 2002, 277, 1972719734, https://doi.org/10.1074/jbc.M201837200.

27. de Haan, C.A.M.; de Wit, M.; Kuo, L.; Montalto-Morrison, C.; Haagmans, B.L.; Weiss, S.R.; Masters, P.S.; Rottier, P.J.M. The glycosylation status of the murine hepatitis coronavirus $M$ protein affects the interferogenic capacity of the virus in vitro and its ability to replicate in the liver but not the brain. Virology 2003, 312, 395-406, https://doi.org/10.1016/S0042-6822(03)00235-6. 
28. Wang, H.; Yang, P.; Liu, K.; Guo, F.; Zhang, Y.; Zhang, G.; Jiang, C. SARS coronavirus entry into host cells through a novel clathrin- and caveolae-independent endocytic pathway. Cell Res 2008, 18, 290-301, https://doi.org/10.1038/cr.2008.15.

29. Ng, M.L.; Tan, S.H., See, E.E.; Ooi, E.E.; Ling, A.E. Proliferative growth of SARS coronavirus in Vero E6 cells. J Gen Virol. 2003, 84, 3291-3303, https://doi.org/10.1099/vir.0.19505-0.

30. Kuo, L.; Masters, P.S. Genetic evidence for a structural interaction between the carboxy termini of the membrane and nucleocapsid proteins of mouse hepatitis virus. J Virol 2002, 76, 4987-4999, https://doi.org/10.1128/jvi.76.10.4987-4999.2002.

31. Keane, S.C.; Giedroc, D.P. Solution of Mouse Hepatit Virus (MHV) nsp3a and determinants of the interaction with MHV nucleocapsid (N) protein. J Virol. 2013, 87, 3502-3515, https://dx.doi.org/10.1128\%2FJVI.03112-12.

32. Weiss, S.R.; Navas-Martin, S. Coronavirus pathogenesis and the emerging pathogen severe acute respiratory syndrome coronavirus. Microbiol Mol Biol Rev 2005, 69, 635-664, https://doi.org/10.1128/MMBR.69.4.635-664.2005.

33. Goldsmith, C.S.; Tatti, K.M.; Ksiazek, T.G.; Rollin, P.E.; Comer, J.A.; Lee, W.W.; Rota, P.A.; Bankamp, B.; Bellini, W.J.; Zaki, S.R. Ultrastructural characterization of SARS coronavirus. Emerg Infect Dis 2004, 10, 320-326, https://doi.org/10.3201/eid1002.030913.

34. Gosert, R.; Kanjanahaluethai, A.; Egger, D.; Bienz, K.; Baker, S.C. RNA replication of mouse hepatitis virus takes place at double-membrane vesicles. J Virol 2002, 76, 3697-3708, https://doi.org/10.1128/jvi.76.8.3697-3708.2002.

35. Lu, R.; Zhao, X.; Li, J.; Niu, P.; Yang, B.; Wu, H.; Wang, W.; Song, H.; Huang, B.; Zhu, N.; Bi, Y.; Ma, X.; Zhan, F.; Wang, L.; Hu, T.; Zhou, H.; Hu, Z.; Zhou, W.; Zhao, L.; Chen, J.; Meng, Y.; Wang, J.; Lin, Y.; Yuan, J.; Xie, Z.; Ma, J.; Liu, W.J.; Wang, D.; Xu, W.; Holmes, E.C.; Gao, G.F.; Wu, G.; Chen, W.; Shi, W.; Tan, W. Genomic characterisation and epidemiology of 2019 novel coronavirus: implications for virus origins and receptor binding. Lancet 2020, 395, 565-574, https://doi.org/10.1016/S0140-6736(20)30251-8.

36. Chen, Y.; Liu, Q.; Guo, D. Emerging coronaviruses: Genome structure, replication, and pathogenesis. Journal of Medical Virology 2020, 92, 418-423, https://doi.org/10.1002/jmv.25681.

37. Keane, S.C.; Giedroc, D.P. Solution structure of mouse hepatitis virus (MHV) nsp3a and determinants of the interaction with MHV nucleocapsid (N) protein. $J$ Virol 2013, 87, 3502-3515, https://doi.org/10.1128/JVI.03112-12.

38. Reguera, J.; Santiago, C.; Mudgal, G.; Ordoño, D.; Enjuanes, L.; Casasnovas, J.M. Structural bases of coronavirus attachment to host aminopeptidase $\mathrm{N}$ and its inhibition by neutralizing antibodies. PLoS Pathog 2012, 8, e1002859-e1002859, https://doi.org/10.1371/journal.ppat.1002859.

39. Xu, L.; Liu, H.; Murray, B.P.; Callebaut, C.; Lee, M.S.; Hong, A.; Strickley, R.G.; Tsai, L.K.; Stray, K.M.; Wang, Y.; Rhodes, G.R.; Desai, M.C. Cobicistat (GS-9350): A Potent and Selective Inhibitor of Human CYP3A as a Novel Pharmacoenhancer. ACS Medicinal Chemistry Letters 2010, 1, 209-213, https://doi.org/10.1021/ml1000257.

40. Bartesaghi, A.; Merk, A.; Borgnia, M.J.; Milne, J.L.S.; Subramaniam, S. Prefusion structure of trimeric HIV1 envelope glycoprotein determined by cryo-electron microscopy. Nature Structural \& Molecular Biology 2013, 20, 1352-1357, http://dx.doi.org/10.1038/nsmb.2711.

41. Hofmann, H.; Hattermann, K.; Marzi, A.; Gramberg, T.; Geier, M.; Krumbiegel, M.; Kuate, S.; Überla, K.; Niedrig, M.; Pöhlmann, S. S Protein of Severe Acute Respiratory Syndrome-Associated Coronavirus Mediates Entry into Hepatoma Cell Lines and Is Targeted by Neutralizing Antibodies in Infected Patients. $J$ Virol 2004, 78, 6134-6142, http://dx.doi.org/10.1128/JVI.78.12.6134-6142.2004.

42. Walls, A.C.; Tortorici, M.A.; Bosch, B.-J.; Frenz, B.; Rottier, P.J.M.; DiMaio, F.; Rey, F.A.; Veesler, D. Cryo-electron microscopy structure of a coronavirus spike glycoprotein trimer. Nature 2016, 531, 114-117, http://dx.doi.org/10.1038/nature16988.

43. Kirchdoerfer, R.N.; Cottrell, C.A.; Wang, N.; Pallesen, J.; Yassine, H.M.; Turner, H.L.; Corbett, K.S.; Graham, B.S.; McLellan, J.S.; Ward, A.B. Pre-fusion structure of a human coronavirus spike protein. Nature 2016, 531, 118-121, http://dx.doi.org/10.1038/nature17200.

44. Lin, X.; Eddy, N.R.; Noel, J.K.; Whitford, P.C.; Wang, Q.; Ma, J.; Onuchic, J.N. Order and disorder control the functional rearrangement of influenza hemagglutinin. Proceedings of the National Academy of Sciences 2014, 111, 12049-12054, http://dx.doi.org/10.1073/pnas.1412849111.

45. Bosch, B.J.; Van Der Zee, R.; de Haan, C.A.M.; Rottier, P.J.M. The coronavirus spike protein is a class I virus fusion protein: structural and functional characterization of the fusion core complex. J. Virol. 2003, 77, 8801-8811, https://doi.org/10.1128/jvi.77.16.8801-8811.2003.

46. Baker, K.A.; Dutch, R.E.; Lamb, R.A.; Jardetzky, T.S. Structural Basis for Paramyxovirus-Mediated Membrane Fusion. Molecular Cell 1999, 3, 309-319, https://doi.org/10.1016/S1097-2765(00)80458-X.

47. Cascella, M.; Rajnik, M.; Cuomo, A.; Dulebohn, S.C.; Napoli, R.D. Features, Evaluation and Treatment Coronavirus (COVID-19). StatPearls Publishing, Treasure Island, FL 2020.

48. Byass, P.; Eco-epidemiological assessment of the COVID-19 epidemic in China, January-February 2020. Glob. Health Action 2020, 13 (1), 1760490, doi: 10.1080/16549716.2020.1760490. 
49. Wu, K.; Li, W.; Peng, G.; Li, F. Crystal structure of NL63 respiratory coronavirus receptor-binding domain complexed with its human receptor. Proc Natl Acad Sci U S A 2009, 106, 19970-19974, https://doi.org/10.1073/pnas.0908837106.

50. Xu, Y.; Lou, Z.; Liu, Y.; Pang, H.; Tien, P.; Gao, G.F.; Rao, Z. Crystal structure of severe acute respiratory syndrome coronavirus spike protein fusion core. J Biol Chem 2004, 279, 49414-49419, http://dx.doi.org/10.1074/jbc.M408782200.

51. Ou, X.; Zheng, W.; Shan, Y.; Mu, Z.; Dominguez, S.R.; Holmes, K.V.; Qian, Z. Identification of the Fusion Peptide-Containing Region in Betacoronavirus Spike Glycoproteins. J Virol 2016, 90, 5586-5600, https://doi.org/10.1128/jvi.00015-16.

52. Lu, G.; Hu, Y.; Wang, Q.; Qi, J.; Gao, F.; Li, Y.; Zhang, Y.; Zhang, W.; Yuan, Y.; Bao, J.; Zhang, B.; Shi, Y.; Yan, J.; Gao, G.F. Molecular basis of binding between novel human coronavirus MERS-CoV and its receptor CD26. Nature 2013, 500, 227-231, http://dx.doi.org/10.1038/nature12328.

53. Lu, L.; Liu, Q.; Zhu, Y.; Chan, K.H.; Qin, L.; Li, Y.; Wang, Q.; Chan, J.F.W.; Du, L.; Yu, F.; Ma, C.; Ye, S.; Yuen, K.-Y.; Zhang, R.; Jiang, S. Structure-based discovery of Middle East respiratory syndrome coronavirus fusion inhibitor. Nature Communications 2014, 5, http://dx.doi.org/10.1038/ncomms4067.

54. Huey, R.; Morris, G. AutoDock Tools. The Scripps Research Institute: La Jolla, CA, USA, 2003.

55. Duquerroy, S.; Vigouroux, A.; Rottier, P.J.; Rey, F.A.; Bosch, B.J. Central ions and lateral asparagine/glutamine zippers stabilize the post-fusion hairpin conformation of the SARS coronavirus spike glycoprotein. Virology 2005, 335, 276-285, https://doi.org/10.1016/j.virol.2005.02.022.

56. Gao, J.; Lu, G.; Qi, J.; Li, Y.; Wu, Y.; Deng, Y.; Geng, H.; Li, H.; Wang, Q.; Xiao, H.; Tan, W.; Yan, J.; Gao, G.F. Structure of the Fusion Core and Inhibition of Fusion by a Heptad Repeat Peptide Derived from the S Protein of Middle East Respiratory Syndrome Coronavirus. J Virol 2013, 87, 13134-13140, http://dx.doi.org/10.1128/JVI.02433-13.

57. Huang, C.; Wang, Y.; Li, X.; Ren, L.; Zhao, J.; Hu, Y.; Zhang, L.; Fan, G.; Xu, J.; Gu, X.; Cheng, Z.; Yu, T.; Xia, J.; Wei, Y.; Wu, W.; Xie, X.; Yin, W.; Li, H.; Liu, M.; Xiao, Y.; Gao, H.; Guo, L.; Xie, J.; Wang, G.; Jiang, R.; Gao, Z.; Jin, Q.; Wang, J.; Cao, B. Clinical features of patients infected with 2019 novel coronavirus in Wuhan, China. The Lancet 2020, 395, 497-506, https://doi.org/10.1016/S01406736(20)30183-5.

58. Monajjemi, M. Graphene/(h-BN)n/X-doped raphene as anode material in lithium ion batteries $(\mathrm{X}=\mathrm{Li}, \mathrm{Be}$, B AND N). Macedonian Journal of Chemistry and Chemical Engineering 2017, 36, 101-118, http://dx.doi.org/10.20450/mjcce.2017.1134.

59. Jalilian, H.; Monajjemi, M. Capacitor simulation including of X-doped graphene (X $=\mathrm{Li}, \mathrm{Be}, \mathrm{B})$ as two electrodes and $(\mathrm{h}-\mathrm{BN}) \mathrm{m}(\mathrm{m}=1-4)$ as the insulator. Japanese Journal of Applied Physics 2015, 54, 0851017.

60. Ardalan, T.; Ardalan, P.; Monajjemi, M. Nano theoretical study of a C 16 cluster as a novel material for vitamin C carrier. Fullerenes Nanotubes and Carbon Nanostructures 2014, 22, 687-708, https://doi.org/10.1080/1536383X.2012.717561.

61. Shang, J.; Ye, G.; Shi, K.; Wan, Y.S.; Aihara, H.; Li, F. Structural basis for resptor recognition by novel coronavirus from wuhan, Structural biology virology 2020, 03-04, https://doi.org/10.21203/rs.2.24749/v1.

62. Xia, S.; Yan, L.; Xu, W.; Agrawal, A.S.; Algaissi, A.; Tseng, C.K.; Wang, Q.; Du, L.; Tan, W.; Wilson, I.A.; Jiang, S.; Yang, B.; Lu, L. A pan-coronavirus fusion inhibitor targeting the HR1 domain of human coronavirus spike. Sci Adv 2019, 5, eaav4580-eaav4580, https://doi.org/doi:10.1126/sciadv.aav4580.

63. Rothe, C.; Schunk, M.; Sothmann, P.; Bretzel, G.; Froeschl, G.; Wallrauch, C.; Zimmer, T.; Thiel, V.; Janke, C.; Guggemos, W.; Seilmaier, M.; Drosten, C.; Vollmar, P.; Zwirglmaier, K.; Zange, S.; Wölfel, R.; Hoelscher, M. Transmission of 2019-nCoV Infection from an Asymptomatic Contact in Germany. New England Journal of Medicine 2020, 382, 970-971, https://doi.org/10.1056/NEJMc2001468.

64. Li, Q.; Guan, X.; Wu, P.; Wang, X.; Zhou, L.; Tong, Y.; Ren, R.; Leung, K.S.M.; Lau, E.H.Y.; Wong, J.Y.; Xing, X.; Xiang, N.; Wu, Y.; Li, C.; Chen, Q.; Li, D.; Liu, T.; Zhao, J.; Liu, M.; Tu, W.; Chen, C.; Jin, L.; Yang, R.; Wang, Q.; Zhou, S.; Wang, R.; Liu, H.; Luo, Y.; Liu, Y.; Shao, G.; Li, H.; Tao, Z.; Yang, Y.; Deng, Z.; Liu, B.; Ma, Z.; Zhang, Y.; Shi, G.; Lam, T.T.Y.; Wu, J.T.; Gao, G.F.; Cowling, B.J.; Yang, B.; Leung, G.M.; Feng, Z. Early Transmission Dynamics in Wuhan, China, of Novel Coronavirus-Infected Pneumonia. New England Journal of Medicine 2020, 382, 1199-1207, https://doi.org/10.1056/NEJMoa2001316.

65. Hafeez, A.; Ahmad, S.; Siddqui, S.A.; Ahmad, M.; Mishra, S. A Review of COVID-19 (Coronavirus Disease-2019) Diagnosis, Treatments and Prevention. EJMO 2020, 4, 116-125, https://doi.org/10.14744/ejmo.2020.90853.

66. Jin, Y.H.; Cai, L.; Cheng, Z.-S.; Cheng, H.; Deng, T.; Fan, Y.P.; Fang, C.; Huang, D.; Huang, L.Q.; Huang, Q.; Han, Y.; Hu, B.; Hu, F.; Li, B.H.; Li, Y.R.; Liang, K.; Lin, L.K.; Luo, L.S..; Ma, J.; Ma, L.L.; Peng, Z.Y.; Pan, Y.B.; Pan, Z.Y.; Ren, X.Q.; Sun, H.M.; Wang, Y.; Wang, Y.Y.; Weng, H.; Wei, C.J.; Wu, D.F.; Xia, J.; Xiong, Y.; Xu, H.B.; Yao, X.M.; Yuan, Y.F.; Ye, T.S.; Zhang, X.C.; Zhang, Y.W.; Zhang, Y.G.; Zhang, H.M.; Zhao, Y.; Zhao, M.J.; Zi, H.; Zeng, X.T.; Wang, Y.Y.; Wang, X.H.; Management, f.t.Z.H.o.W.U.N.C.; Research Team, E.-B.M.C.o.C.I.E.; Promotive Association for, M.; Health, C. A rapid 
advice guideline for the diagnosis and treatment of 2019 novel coronavirus (2019-nCoV) infected pneumonia (standard version). Military Medical Research 2020, 7, https://doi.org/10.1186/s40779-020-0233-6.

67. Li, F. Receptor Recognition Mechanisms of Coronaviruses: a Decade of Structural Studies. J Virol 2015, 89, 1954-1964, http://dx.doi.org/10.1128/JVI.02615-14.

68. Reguera, J.; Santiago, C.; Mudgal, G.; Ordoño, D.; Enjuanes, L.; Casasnovas, J.M. Structural Bases of Coronavirus Attachment to Host Aminopeptidase $\mathrm{N}$ and Its Inhibition by Neutralizing Antibodies. PLoS Pathog 2012, 8, e1002859, http://dx.doi.org/10.1371/journal.ppat.1002859.

69. Li, W.; Zhang, C.; Sui, J.; Kuhn, J.H.; Moore, M.J.; Luo, S.; Wong, S.-K.; Huang, I.C.; Xu, K.; Vasilieva, N.; Murakami, A.; He, Y.; Marasco, W.A.; Guan, Y.; Choe, H.; Farzan, M. Receptor and viral determinants of SARS-coronavirus adaptation to human ACE2. The EMBO Journal 2005, 24, 1634-1643, http://dx.doi.org/10.1038/sj.emboj.7600640.

70. Phelan, A.L.; Katz, R.; Gostin, L.O. The Novel Coronavirus Originating in Wuhan, China: Challenges for Global Health Governance. JAMA 2020, 323, 709-710, https://doi.org/10.1001/jama.2020.1097.

71. Gorbalenya, A.E.; Baker, S.C.; Baric, R.S.; de Groot, R.J.; Drosten, C.; Gulyaeva, A.A.; Haagmans, B.L.; Lauber, C.; Leontovich, A.M.; Neuman, B.W.; Penzar, D.; Perlman, S.; Poon, L.L.M.; Samborskiy, D.; Sidorov, I.A.; Sola, I.; Ziebuhr, J. \&lt;em\&gt;Severe acute respiratory syndrome-related coronavirus\&lt;/em\&gt;: The species and its viruses - a statement of the Coronavirus Study Group. bioRxiv 2020, https://doi.org/10.1101/2020.02.07.937862.

72. Bonavia, A.; Zelus, B.D.; Wentworth, D.E.; Talbot, P.J.; Holmes, K.V. Identification of a receptor-binding domain of the spike glycoprotein of human coronavirus HCoV-229E. J Virol 2003, 77, 2530-2538, http://dx.doi.org/10.1128/JVI.77.4.2530-2538.2003.

73. Russell, C.D.; Millar, J.E.; Baillie, J.K. Clinical evidence does not support corticosteroid treatment for 2019nCoV lung injury. The Lancet 2020, 395, 473-475, https://doi.org/10.1016/S0140-6736(20)30317-2.

74. Zhao, J.P.; Hu, Y.; Du, R.H.; Chen, Z.S.; Jin, Y.; Zhou, M.; Zhang, J.; Qu, J.M.; Cao, B. [Expert consensus on the use of corticosteroid in patients with 2019-nCoV pneumonia]. Zhonghua Jie He He Hu Xi Za Zhi 2020, 43, E007.

75. Mukherjee, R; Global efforts on vaccines for COVID-19: Since, sooner or later, we all will catch the coronavirus. J. Biosci. 2020, 45 (1), 68, doi: 10.1007/s12038-020-00040-7.

76. Zhang, L.; Liu, Y. Potential interventions for novel coronavirus in China: A systematic review. Journal of Medical Virology 2020, 92, 479-490, https://doi.org/10.1002/jmv.25707.

77. Sanders, J.M.; Monogue, M.L.; Jodlowski, T.Z.; Cutrell, J.B. Pharmacologic Treatments for Coronavirus Disease 2019 (COVID-19): A Review. JAMA 2020, 323, 1824-1836, https://doi.org/10.1001/jama.2020.6019.

78. Grein, J.; Ohmagari, N.; Shin, D.; Diaz, G.; Asperges, E.; Castagna, A.; Feldt, T.; Green, G.; Green, M.L.; Lescure, F.-X.; Nicastri, E.; Oda, R.; Yo, K.; Quiros-Roldan, E.; Studemeister, A.; Redinski, J.; Ahmed, S.; Bernett, J.; Chelliah, D.; Chen, D.; Chihara, S.; Cohen, S.H.; Cunningham, J.; D’Arminio Monforte, A.; Ismail, S.; Kato, H.; Lapadula, G.; L’Her, E.; Maeno, T.; Majumder, S.; Massari, M.; Mora-Rillo, M.; Mutoh, Y.; Nguyen, D.; Verweij, E.; Zoufaly, A.; Osinusi, A.O.; DeZure, A.; Zhao, Y.; Zhong, L.; Chokkalingam, A.; Elboudwarej, E.; Telep, L.; Timbs, L.; Henne, I.; Sellers, S.; Cao, H.; Tan, S.K.; Winterbourne, L.; Desai, P.; Mera, R.; Gaggar, A.; Myers, R.P.; Brainard, D.M.; Childs, R.; Flanigan, T. Compassionate Use of Remdesivir for Patients with Severe Covid-19. New England Journal of Medicine 2020.

79. Shen, C.; Wang, Z.; Zhao, F.; Yang, Y.; Li, J.; Yuan, J.; Wang, F.; Li, D.; Yang, M.; Xing, L.; Wei, J.; Xiao, H.; Yang, Y.; Qu, J.; Qing, L.; Chen, L.; Xu, Z.; Peng, L.; Li, Y.; Zheng, H.; Chen, F.; Huang, K.; Jiang, Y.; Liu, D.; Zhang, Z.; Liu, Y.; Liu, L. Treatment of 5 Critically Ill Patients With COVID-19 With Convalescent Plasma. JAMA 2020, 323, 1582-1589, https://doi.org/10.1001/jama.2020.4783.

80. Li, J.; Li, J.; Xie, X.; Cai, X.; Huang, J.; Tian, X.; Zhu, H. Game consumption and the 2019 novel coronavirus. The Lancet Infectious Diseases 2020, 20, 275-276, https://doi.org/10.1016/S14733099(20)30063-3.

81. Her, M; Repurposing and reshaping of hospitals during the COVID-19 outbreak in South Korea. One Health 2020, 10, 100137, doi: 10.1016/j.onehlt.2020.100137.

82. Wang, D.; Hu, B.; Hu, C.; Zhu, F.; Liu, X.; Zhang, J.; Wang, B.; Xiang, H.; Cheng, Z.; Xiong, Y.; Zhao, Y.; Li, Y.; Wang, X.; Peng, Z. Clinical Characteristics of 138 Hospitalized Patients With 2019 Novel Coronavirus-Infected Pneumonia in Wuhan, China. JAMA 2020, 323, 1061-1069, https://doi.org/10.1001/jama.2020.1585.

83. Chen, N.; Zhou, M.; Dong, X.; Qu, J.; Gong, F.; Han, Y.; Qiu, Y.; Wang, J.; Liu, Y.; Wei, Y.; Xia, J.a.; Yu, T.; Zhang, X.; Zhang, L. Epidemiological and clinical characteristics of 99 cases of 2019 novel coronavirus pneumonia in Wuhan, China: a descriptive study. The Lancet 2020, 395, 507-513, https://doi.org/10.1016/S0140-6736(20)30211-7.

84. Yang, X.; Yu, Y.; Xu, J.; Shu, H.; Xia, J.a.; Liu, H.; Wu, Y.; Zhang, L.; Yu, Z.; Fang, M.; Yu, T.; Wang, Y.; Pan, S.; Zou, X.; Yuan, S.; Shang, Y. Clinical course and outcomes of critically ill patients with SARS-CoV2 pneumonia in Wuhan, China: a single-centered, retrospective, observational study. The Lancet Respiratory Medicine 2020, 8, 475-481, https://doi.org/10.1016/S2213-2600(20)30079-5. 
85. Zou, L.; Ruan, F.; Huang, M.; Liang, L.; Huang, H.; Hong, Z.; Yu, J.; Kang, M.; Song, Y.; Xia, J.; Guo, Q.; Song, T.; He, J.; Yen, H.-L.; Peiris, M.; Wu, J. SARS-CoV-2 Viral Load in Upper Respiratory Specimens of Infected Patients. New England Journal of Medicine 2020, 382, 1177-1179, https://doi.org/10.1056/NEJMc2001737.

86. Qiu, H.; Tong, Z.; Ma, P.; Hu, M.; Peng, Z.; Wu, W.; Du, B.; China Critical Care Clinical Trials, G. Intensive care during the coronavirus epidemic. Intensive Care Medicine 2020, 46, 576578, https://doi.org/10.1007/s00134-020-05966-y.

87. van Doremalen, N.; Bushmaker, T.; Morris, D.H.; Holbrook, M.G.; Gamble, A.; Williamson, B.N.; Tamin, A.; Harcourt, J.L.; Thornburg, N.J.; Gerber, S.I.; Lloyd-Smith, J.O.; de Wit, E.; Munster, V.J. Aerosol and Surface Stability of SARS-CoV-2 as Compared with SARS-CoV-1. New England Journal of Medicine 2020, 382, 1564-1567, https://doi.org/10.1056/NEJMc2004973.

88. Wang, Z.; Chen, X.; Lu, Y.; Chen, F.; Zhang, W. Clinical characteristics and therapeutic procedure for four cases with 2019 novel coronavirus pneumonia receiving combined Chinese and Western medicine treatment. BioScience Trends 2020, 14, 64-68, https://doi.org/10.5582/bst.2020.01030.

89. Arabi, Y.M.; Fowler, R.; Hayden, F.G. Critical care management of adults with community-acquired severe respiratory viral infection. Intensive Care Medicine 2020, 46, 315-328, https://doi.org/10.1007/s00134-02005943-5.

90. Sun, P.; Qie, S.; Liu, Z.; Ren, J.; Li, K.; Xi, J. Clinical characteristics of hospitalized patients with SARSCoV-2 infection: A single arm meta-analysis. Journal of Medical Virology 2020, 92, 612617, https://doi.org/10.1002/jmv.25735.

91. Wang, Y.; Fan, G.; Salam, A.; Horby, P.; Hayden, F.G.; Chen, C.; Pan, J.; Zheng, J.; Lu, B.; Guo, L.; Wang, C.; Cao, B.; Community-Acquired Pneumonia China, N. Comparative Effectiveness of Combined Favipiravir and Oseltamivir Therapy Versus Oseltamivir Monotherapy in Critically Ill Patients With Influenza Virus Infection. The Journal of Infectious Diseases 2019, 221, 16881698, https://doi.org/10.1093/infdis/jiz656.

92. Cao, B.; Wang, Y.; Wen, D.; Liu, W.; Wang, J.; Fan, G.; Ruan, L.; Song, B.; Cai, Y.; Wei, M.; Li, X.; Xia, J.; Chen, N.; Xiang, J.; Yu, T.; Bai, T.; Xie, X.; Zhang, L.; Li, C.; Yuan, Y.; Chen, H.; Li, H.; Huang, H.; Tu, S.; Gong, F.; Liu, Y.; Wei, Y.; Dong, C.; Zhou, F.; Gu, X.; Xu, J.; Liu, Z.; Zhang, Y.; Li, H.; Shang, L.; Wang, K.; Li, K.; Zhou, X.; Dong, X.; Qu, Z.; Lu, S.; Hu, X.; Ruan, S.; Luo, S.; Wu, J.; Peng, L.; Cheng, F.; Pan, L.; Zou, J.; Jia, C.; Wang, J.; Liu, X.; Wang, S.; Wu, X.; Ge, Q.; He, J.; Zhan, H.; Qiu, F.; Guo, L.; Huang, C.; Jaki, T.; Hayden, F.G.; Horby, P.W.; Zhang, D.; Wang, C. A Trial of Lopinavir-Ritonavir in Adults Hospitalized with Severe Covid-19. New England Journal of Medicine 2020, 382, 17871799, https://doi.org/10.1056/NEJMoa2001282.

93. Gordon, C.J.; Tchesnokov, E.P.; Feng, J.Y.; Porter, D.P.; Götte, M. The antiviral compound remdesivir potently inhibits RNA-dependent RNA polymerase from Middle East respiratory syndrome coronavirus. $J$ Biol Chem 2020, 295, 4773-4779, https://doi.org/10.1074/jbc.AC120.013056.

94. de Wit, E.; Feldmann, F.; Cronin, J.; Jordan, R.; Okumura, A.; Thomas, T.; Scott, D.; Cihlar, T.; Feldmann, H. Prophylactic and therapeutic remdesivir (GS-5734) treatment in the rhesus macaque model of MERS$\mathrm{CoV}$ infection. Proceedings of the National Academy of Sciences 2020, 117, 67716776, https://doi.org/10.1073/pnas.1922083117.

95. Lu, H. Drug treatment options for the 2019-new coronavirus (2019-nCoV). BioScience Trends 2020, 14, 6971, https://doi.org/10.5582/bst.2020.01020.

96. Wang, M.; Cao, R.; Zhang, L.; Yang, X.; Liu, J.; Xu, M.; Shi, Z.; Hu, Z.; Zhong, W.; Xiao, G. Remdesivir and chloroquine effectively inhibit the recently emerged novel coronavirus (2019-nCoV) in vitro. Cell Research 2020, 30, 269-271, https://doi.org/10.1038/s41422-020-0282-0.

97. Yao, X.; Ye, F.; Zhang, M.; Cui, C.; Huang, B.; Niu, P.; Liu, X.; Zhao, L.; Dong, E.; Song, C.; Zhan, S.; Lu, R.; Li, H.; Tan, W.; Liu, D. In Vitro Antiviral Activity and Projection of Optimized Dosing Design of Hydroxychloroquine for the Treatment of Severe Acute Respiratory Syndrome Coronavirus 2 (SARS-CoV2). Clinical Infectious Diseases 2020, https://doi.org/10.1093/cid/ciaa237.

98. Chen, L.; Xiong, J.; Bao, L.; Shi, Y. Convalescent plasma as a potential therapy for COVID-19. The Lancet Infectious Diseases 2020, 20, 398-400, https://doi.org/10.1016/s1473-3099(20)30141-9.

99. Alhazzani, W.; Møller, M.H.; Arabi, Y.M.; Loeb, M.; Gong, M.N.; Fan, E.; Oczkowski, S.; Levy, M.M.; Derde, L.; Dzierba, A.; Du, B.; Aboodi, M.; Wunsch, H.; Cecconi, M.; Koh, Y.; Chertow, D.S.; Maitland, K.; Alshamsi, F.; Belley-Cote, E.; Greco, M.; Laundy, M.; Morgan, J.S.; Kesecioglu, J.; McGeer, A.; Mermel, L.; Mammen, M.J.; Alexander, P.E.; Arrington, A.; Centofanti, J.E.; Citerio, G.; Baw, B.; Memish, Z.A.; Hammond, N.; Hayden, F.G.; Evans, L.; Rhodes, A. Surviving Sepsis Campaign: guidelines on the management of critically ill adults with Coronavirus Disease 2019 (COVID-19). Intensive Care Medicine 2020, 46, 854-887, https://doi.org/10.1007/s00134-020-06022-5.

100. MacLaren, G.; Fisher, D.; Brodie, D. Preparing for the Most Critically Ill Patients With COVID-19: The Potential Role of Extracorporeal Membrane Oxygenation. JAMA 2020, 323, 12451246, https://doi.org/10.1001/jama.2020.2342.

101. Poston, J.T.; Patel, B.K.; Davis, A.M. Management of Critically Ill Adults With COVID-19. JAMA 2020, 323, 1839-1841, https://doi.org/10.1001/jama.2020.4914. 